\title{
The effects of a strong winter storm on physical and biological variables at a shelf site in the Mediterranean
}

\author{
Effets d'une forte tempête hivernale sur les variables physiques \\ et biologiques à une station côtière méditerranéenne
}

\author{
Antoine Grémare ${ }^{\mathrm{a}, *}$, Jean-Michel Amouroux ${ }^{\mathrm{a}}$, Gustave Cauwet ${ }^{\mathrm{a}}$, \\ François Charles ${ }^{\mathrm{a}}$, Claude Courties ${ }^{\mathrm{b}}$, Francis De Bovée ${ }^{\mathrm{a}}$, Alain Dinet ${ }^{\mathrm{a}}$, Jean Luc Devenon ${ }^{\mathrm{c}}$, \\ Xavier Durrieu De Madron ${ }^{\mathrm{d}}$, Béatrice Ferre ${ }^{\mathrm{d}}$, Philippe Fraunie ${ }^{\mathrm{c}}$, Fabien Joux ${ }^{\mathrm{a}}$, \\ François Lantoine ${ }^{\mathrm{a}}$, Philippe Lebaron ${ }^{\mathrm{a}}$, Jean-Jacques Naudin ${ }^{\mathrm{a}}$, Albert Palanques ${ }^{\mathrm{e}}$, \\ Mireille Pujo-Pay ${ }^{\mathrm{a}}$, Laurent Zudaire ${ }^{\mathrm{f}}$ \\ a Observatoire Océanologique de Banyuls, Laboratoire d'Océanographie Biologique, UMR 7621, CNRS-UPMC, 66651 Banyuls-sur-Mer cedex, France \\ ${ }^{b}$ Observatoire Océanologique de Banyuls, Modèles marins en Biologie Cellulaire et Evolutive, \\ UMR 7628, CNRS-UPMC, 66651 Banyuls-sur-Mer cedex, France \\ c Laboratoire de Sondages Electromagnétiques de l'Environnement Terrestre, \\ URA CNRS 705, Université de Toulon, BP132, 83957 La Garde cedex, France \\ ${ }^{a}$ Centre de Formation et de Recherche sur l'Environnement Marin, UMR 5110, CNRS, Université de Perpignan, \\ 52, avenue de Villeneuve, 66860 Perpignan cedex, France \\ e Institut de Ciències del Mar, CMIMA-CSIC, Passeig Marítim de la Barceloneta, $37-4908003$ Barcelona, Spain \\ ${ }^{f}$ Observatoire Océanologique de Banyuls, UMS 2348, CNRS-UPMC, 66651 Banyuls-sur-Mer cedex, France
}

Received 13 November 2001; received in revised form 4 July 2002; accepted 20 September 2002

\begin{abstract}
A survey involving both permanent mooring and high frequency sampling was carried in the Bay of Banyuls-sur-Mer during the fall of 1999 to assess the effect of strong and unpredictable meteorological events on the functioning of a coastal Mediterranean ecosystem. A severe winter storm took place on 12 November, which generated waves with a significant height of $7 \mathrm{~m}$ and a sea surface rise of about $0.5 \mathrm{~m}$. The near-bottom current speed at $24 \mathrm{~m}$ reached $30 \mathrm{~cm} \mathrm{~s}^{-1}$. This storm induced a significant increase in total suspended matter through resuspension and then a subsequent increase in gross sedimentation rates. It also resulted in an increase of the proportion of refractory particulate organic matter in the water column. It also tended to increase nutrient availability in the water column through resuspension and desorption processes. The kinetic of this increase differed among nutrients. Bacterial biomass and production were significantly enhanced by the storm. These effects were transitory and probably not due to resuspension alone. The distribution of plant pigments was modified at the immediate vicinity of the water-sediment interface due to differential resuspension and sedimentation but the storm had no effect on integrated phytoplanktonic biomass. Such a lack of response may be linked to low precipitations and/or light limitation. The storm resulted in a transitory increase of the abundance of fine particles at the water-sediment interface. These particles were coated with refractory organic matter. The storm induced a significant decrease of meiofauna abundance. The duration of the relaxation periods varied among parameters. It lasted 2 weeks for total suspended matter, surface sediment granulometry and carbohydrate contents.
\end{abstract}

(C) 2003 Éditions scientifiques et médicales Elsevier SAS and Ifremer/CNRS/IRD. All rights reserved.

\section{Résumé}

Une étude faisant intervenir des mouillages permanents et un échantillonnage haute fréquence a été conduite en baie de Banyuls-sur-Mer pendant l'automne 1999 afin de déterminer les effets d'événements météorologiques forts et imprévisibles sur le fonctionnement d'un

\footnotetext{
* Corresponding author.

E-mail address: gremare@obs-banyuls.fr (A. Grémare).
} 
écosystème côtier méditerranéen. Une forte tempête hivernale a eu lieu le 12 novembre 1999. Cette tempête a engendré des vagues dont la hauteur était proche de 7 mètres ainsi qu'une élévation du niveau de la mer voisine d'un demi-mètre. La vitesse du courant à 24 mètres de profondeur a alors atteint $30 \mathrm{~cm} \mathrm{~s}^{-1}$. Cette tempête a induit une augmentation significative de la concentration de matières en suspension dans l'eau puis une augmentation des taux de sédimentation brute. Elle a également résulté en une augmentation de la proportion de matière organique particulaire réfractaire dans la colonne d'eau. La tempête a également contribué à augmenter la disponibilité des sels nutritifs dans la colonne d'eau. La cinétique de cette augmentation a cependant différé d'un sel à l'autre. La biomasse et la production bactérienne ont toutes deux été positivement affectées par la tempête. Ces augmentations ont été transitoires et n'étaient probablement pas liées au seul processus de resuspension. La composition pigmentaire du phytoplancton a été modifiée à proximité immédiate de l'interface eau-sédiment mais la tempête n'a pas eu d'effet significatif sur la biomasse phytoplanctonique intégrée. Une telle absence de réponse pourrait être liée à la faiblesse des précipitations et/ou à une limitation par la lumière. La tempête a induit une augmentation transitoire de la proportion de particules fines à la surface du sédiment. Ces particules étaient associées à de la matière organique réfractaire. La tempête a également engendré une diminution significative de l'abondance de la meiofaune. La durée de la période de relaxation a varié d'un paramètre à l'autre. Elle a duré deux semaines pour les matières en suspension ainsi que pour la granulométrie et le contenu en carbohydrates des sédiments de surface.

(C) 2003 Éditions scientifiques et médicales Elsevier SAS and Ifremer/CNRS/IRD. All rights reserved.

Keywords: Impact of storm; NW Mediterranean Sea; Coastal ecosystem

Mots clés : Impact à une tempête ; Méditerranée nord-occidentale ; Ecosystème côtier

\section{Introduction}

The frequent occurrence of disturbances is one of the main characteristics of coastal ecosystems. These perturbations usually result in an increase in organic matter availability originating either from anthropogenic inputs or from defaunation. The first surveys assessing the effects of perturbations on coastal systems were carried out during the 1970s. They dealt with the structures of benthic communities and have been summarised by Pearson and Rosenberg (1978).

Winds and associated storms are clearly one of the major causes of disturbance in coastal ecosystems. They often result in sediment resuspension, which may affect the functioning of coastal ecosystems through changes in nutrient, light, and organic matter availability. So far, field surveys assessing the effects of wind-induced resuspension on the functioning of coastal ecosystems have been mostly carried out in estuaries (Shideler, 1984; Gabrielson and Luketelich, 1985; Demers et al., 1987; Weir and MacManus, 1987; Simon, 1989) and in coastal lagoons (Arfi et al., 1993, 1994; Bouvy et al., 1994; Arfi and Bouvy, 1995). Results from such studies showed: (1) a direct effect of resuspension on both the quantity and the size spectra of suspended particles, and (2) an indirect effect (through nutrient regeneration and light conditions) on both phytoplanktonic (Arfi et al., 1993) and bacterial communities (Wainright, 1987; Ritzrau and Graf, 1992). All these effects are likely to be emphasised in microtidal seas such as the Mediterranean due to the absence of tide-induced resuspension. Increased nutrient availability may also have important consequences in oligotrophic areas such as the Mediterranean.

Temporal changes in gross sedimentation rates (GSRs) and in the biochemical characteristics of sedimenting particulate organic matter (POM) within the Bay of Banyulssur-Mer (NW Mediterranean) have been extensively studied (Grémare et al., 1997, 1998; Medernach et al., 2001). Results showed the existence of two different periods during each year. The spring-summer period is characterised by low GSRs and by comparatively high POM organic contents, whereas the autumn-winter period is characterised by highly variable and occasionally very high GSRs and by comparatively low POM organic contents. The shape of the relationship linking GSRs and organic contents of sedimenting POM suggests that sediment resuspension is important for both the amount and the characteristics of suspended particles within the bay (Grémare et al., 1997). In this area, sediment resuspension is mostly caused by easterly winds, which can induce strong swells during wintertime. The nutritional value of sedimenting POM shows important temporal changes as evidenced by the results of bioassays involving either absorption (Charles et al., 1995) or growth measurements of benthic fauna (Grémare et al., 1997) and by the analysis of bioavailable compounds (Medernach et al., 2001). It is suspected that winter storms induce a decrease in sedimenting POM nutritional value, and changes in POM amino acid spectra (Medernach et al., 2001). Such events are thus likely to have important consequences on ecosystem functioning. All the surveys carried out within the Bay of Banyuls-sur-Mer have involved a fixed sampling interval of either 1 or 2 weeks. Therefore, the short-term consequences of winter storms on ecosystem functioning are yet to be studied. Moreover, most of the analytical effort so far, has been put on the assessment of: (1) general meteorological parameters, (2) GSRs, and (3) biochemical characteristics of sedimenting POM, and a large set of important physical, chemical and biological parameters have been ignored.

The aim of the present study was to perform a comprehensive analysis on how winter storms influence the functioning of a coastal Mediterranean ecosystem. Our specific working hypotheses were that: (1) sediment resuspension would increase the amount and modify the characteristics of suspended POM, (2) storm would enhance the transfer of nutrient and possibly dissolved organic matter between the sediment and the water column, (3) both bacteria and phy- 


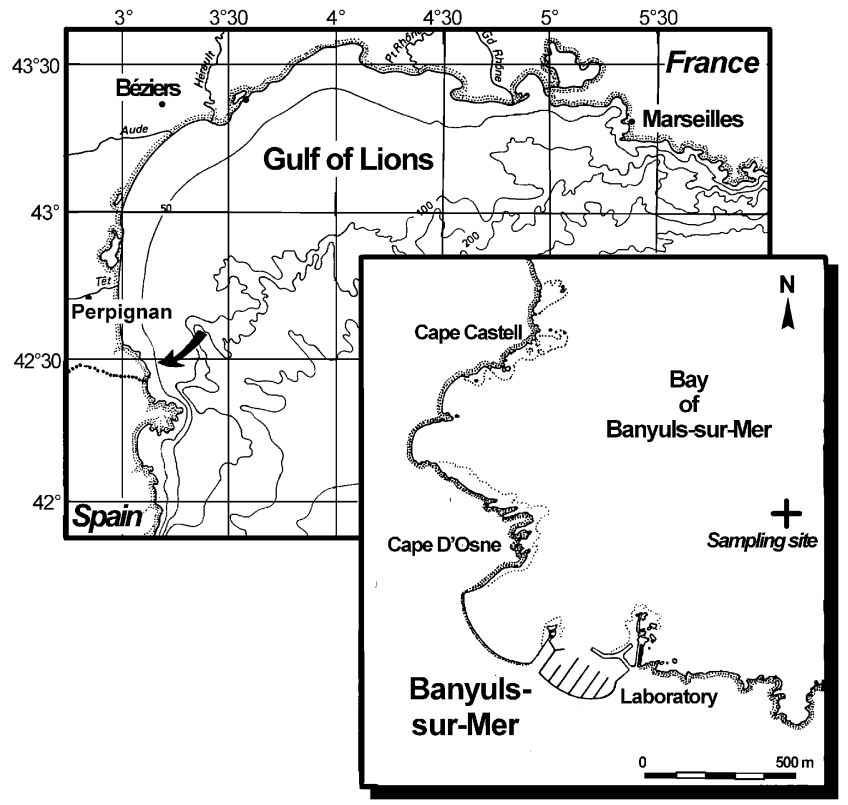

Fig. 1. Map of the Bay of Banyuls-sur-Mer showing the location of the studied site.

toplankton could benefit from such increased concentrations in the water column, (4) sediment resuspension would result in significant changes in the granulometry and the biochemical characteristics of superficial sediment, and (5) storm would affect the abundance of benthic meiofauna. These hypotheses were tested by using both continuous time series (permanent moorings) and high frequency sampling between 26 October and 11 December 1999. This allowed for the assessment of temporal changes before, during and after the severe winter storm that occurred on 12 November. This strategy was especially suitable in view of the assessment of the duration of the time periods required for the return to pre-storm conditions (i.e. relaxation periods).

\section{Materials and methods}

The study took place at a $26.3 \mathrm{~m}$ deep site $\left(42^{\circ} 29^{\prime} 366^{\prime \prime} \mathrm{N}\right.$, $\left.03^{\circ} 08^{\prime} 625^{\prime} \mathrm{E}\right)$ located within the Bay of Banyuls-sur-Mer Fig. 1.

\subsection{Meteorological data}

Hourly averaged wind speed and direction were measured by Météo-France $3 \mathrm{~km}$ north from the studied site. Sea surface elevation was measured by the Service Maritime et de Navigation du Languedoc-Roussillon at the Sète harbour.

\subsection{Moorings}

Wave height and period were measured at the studied site using a Datawell ${ }^{\circledR}$ non-directional system. Near-bottom currents were measured with a self-contained RDI ${ }^{\circledR}$ Broadband $300 \mathrm{kHz}$. This downward looking ADCP was moored $5 \mathrm{~m}$ above the bottom. The cell size was $20 \mathrm{~cm}$ and the profiling depth ranged between 22 and $26 \mathrm{~m}$. The burst sampling rate was set to 15 min and each burst averaged about 100 profiles during 2 min. Two Aanderaa ${ }^{\circledR}$ optical backscatter sensors (OBS) with two different sensitivity range (0-5 and $0-21$ NTU, respectively) were deployed on a separate line $3 \mathrm{~m}$ above the bottom. Their sampling rates were set to $5 \mathrm{~min}$. Suspended particle size distributions were measured with a Malvern ${ }^{\circledR}$ Mastersizer 2000 laser microgranulometer and used to convert the acoustic backscatter intensity of the RDI ${ }^{\circledR}$ ADCP using the Sediview ${ }^{\circledR}$ software.

Two sets of sediment traps (see the description in Charles et al., 1995) were deployed at 10 and $23 \mathrm{~m}$ depth. Their contents were collected about twice a week by Scuba divers. They were immediately taken to the laboratory where they were centrifuged (4000 rpm, $15 \mathrm{~min}$ ), frozen, briefly rinsed with distilled water, freeze-dried and weighed. This material was then sieved on a $200 \mu \mathrm{m}$ mesh and stored at $-20{ }^{\circ} \mathrm{C}$. Granulometry was assessed using a Malvern ${ }^{\circledR}$ Mastersizer 2000 laser microgranulometer. Organic contents were assessed by measuring the weight lost after combustion $\left(450^{\circ} \mathrm{C}, 5 \mathrm{~h}\right)$. Carbohydrates were assayed after Dubois et al. (1956). Lipids were assayed after Barnes and Blackstock (1973). All these analyses were run on triplicates.

\subsection{Water column measurements}

The studied site was sampled 25 times using the R/V Nereis. During each cruise, a profile was carried out using a Seabird $^{\circledR}$ 9/11 plus CTD equipped with a fluorometer (Chelsea ${ }^{\circledR}$ Acquatracka III) and a transmissiometer (SeaT$\mathrm{ech}^{\circledR}$ ) and 121 water samples were collected just below the surface and at 7,15 and $22 \mathrm{~m}$ depth. Whenever possible a fifth sample (10 1) was taken by Scuba divers at the immediate vicinity of the seabed.

Whatman GF/F glass fibre filters were used for total suspended matter (TSM) measurements. Filters were previously pre-combusted at $450{ }^{\circ} \mathrm{C}$ and weighed to the nearest $10^{-2} \mathrm{mg}$. Duplicated samples were filtered and briefly rinsed with distilled water. Filters were dried for $24 \mathrm{~h}$ at $60{ }^{\circ} \mathrm{C}$ and then re-weighed.

Duplicated samples for inorganic nutrients were filtered. Ammonia $\left(\mathrm{NH}_{4}\right)$ was immediately assayed according to Koroleff (1969). Samples for nitrate $\left(\mathrm{NO}_{3}\right)$, nitrite $\left(\mathrm{NO}_{2}\right)$ and phosphate $\left(\mathrm{PO}_{4}\right)$ determinations were frozen $\left(-20{ }^{\circ} \mathrm{C}\right)$. They were assayed using an automated colorimetric technique (Skalar ${ }^{\circledR}$ Auto-Analyser; Tréguer and Le Corre, 1975).

Samples for dissolved organic nitrogen (DON) and phosphorus (DOP) were filtered on pre-combusted Whatman GF/F filters, collected in Teflon bottles and immediately frozen prior analysis. DON and DOP were determined simultaneously by the wet oxidation procedure described in PujoPay and Raimbault (1994). Samples for dissolved organic carbon (DOC) were filtered on pre-combusted Whatman $\mathrm{GF} / \mathrm{F}$ filters and collected in pre-combusted glass tubes, poisoned with mercury chloride $\left(5 \mathrm{mg} \mathrm{l}^{-1}\right)$ and sealed with Teflon lined screw caps. Further analysis of DOC was per- 
formed using a high temperature catalytic oxidation (HTCO) technique (Cauwet, 1994) with a Shimadzu ${ }^{\circledR}$ TOC 5000 analyser.

Chlorophyll and phaeophytin $a, b$ and $c$ were determined according to Neveux and Lantoine (1993). Water samples were passed on GF/F filter, which were immediately frozen in liquid nitrogen. Filters were extracted in $90 \%$ acetone (final concentration). Extracts were kept at $4{ }^{\circ} \mathrm{C}$ for $12 \mathrm{~h}$ and centrifuged before supernatants were passed on a Perkin Elmer ${ }^{\circledR}$ MPF66 spectrofluorometer.

Samples for bacterial cell counts were preserved with $2 \%$ $0.22 \mu \mathrm{m}$ prefiltered formalin and stored in liquid nitrogen (Troussellier et al., 1995). Total bacteria were stained with $0.5 \mu \mathrm{l}$ of SYBR-II (nucleic acid stain, Molecular Probes $\mathrm{Inc}^{\circledR}$ ) during $15 \mathrm{~min}$ at room temperature in the dark (Lebaron et al., 1998). Stained bacteria were discriminated and counted on a Becton Dickinson ${ }^{\circledR}$ FACScan flow cytometer equipped with an air-cooled argon laser (488 nm, $15 \mathrm{~mW})$, according to their right angle light scatter and the green fluorescence measured at 530/30 nm. Bacterial carbon was computed assuming a cellular content of $20 \mathrm{fg} C$ per cell (Lee and Furhman, 1987). Bacterial production was determined according to Furhman and Azam (1982). Three aliquots of 10 $\mathrm{ml}$ each were supplemented with $\left[{ }^{3} \mathrm{H}\right.$-methyl] thymidine $\left(\right.$ IsotopChim $^{\circledR}$ ) at a final concentration of $20 \mathrm{nM}$. Two additional aliquots were fixed (formalin, $2 \%$ final concentration) before addition of thymidine and used as blanks. The saturating concentration was determined during concentrationdependent incorporation experiments performed at the beginning of the study. Samples were incubated in the dark at in situ temperature for $1 \mathrm{~h}$ and then fixed with formalin (2\% final concentration). They were then filtered onto $0.2 \mu \mathrm{m}$ nitrocellulose membranes (GSWP, Millipore ${ }^{\circledR}$, France), extracted with cold 5\% trichloroacetic acid (TCA) for $10 \mathrm{~min}$ and rinsed twice with $10 \mathrm{ml}$ cold 5\% TCA. Filters were dissolved with liquid scintillation (FilterCount, Packard BioSciences ${ }^{\circledR}$, France) in scintillation vials and radioactivity was quantified in a liquid scintillation counter (LS 5000CE, Beckman $^{\circledR}$ ). Thymidine incorporation were converted to carbon production using a conversion factor of $0.5 \times 10^{18}$ cells $\mathrm{mol}^{-1}$ of thymidine incorporated (Servais and Lavandier, 1995) and using a cell-to-carbon conversion factor of $20 \mathrm{fg} \mathrm{C}$ per cell (Lee and Furhman, 1987).

\subsection{Sediments and meiofauna}

Eleven times during the studied period, three sediment cores $(5.2 \mathrm{~cm}$ in diameter) were taken by Scuba divers. Their first centimetres were analysed for the same parameters and using the same protocols as described for sediment trap materials. On seven occasions, five additional cores $(2 \mathrm{~cm}$ in diameter) were collected and their first $7 \mathrm{~cm}$ were extracted for meiofauna by seven repeated shakings in 51 of tap water and by sieving on a $40 \mu \mathrm{m}$ mesh. Metazoan meiofauna was then fixed in 10\% formalin and stained with Rose Bengale. Animals were identified to the main taxa and counted under a dissecting microscope.

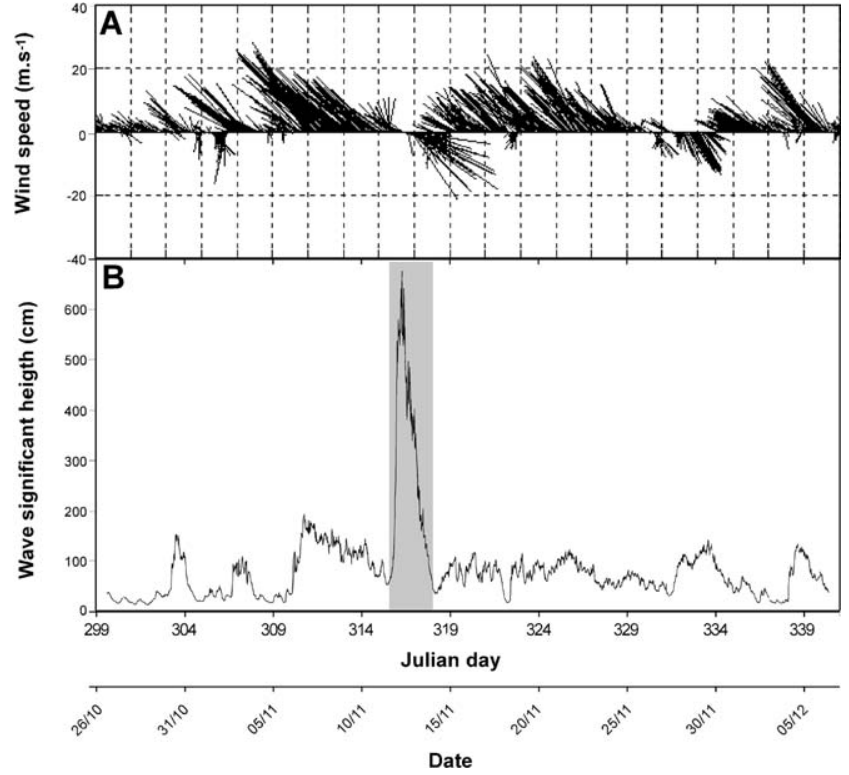

Fig. 2. Temporal changes in the wind regime (A) and the significant wave height (B) during the period under study. The shaded area corresponds to the storm. In A, vertical corresponds to true North.

\section{Results}

\subsection{Meteorological data}

The stickplot of the wind is presented in Fig. 2A. Northwesterly winds were clearly dominant, except during three periods (30 October-1 November, 11-13 November, and 25-29 November) where south-easterly winds occurred. Among these three periods, the one between 11 and 13 November was associated to the strongest winds (up to $30 \mathrm{~m}$ $\mathrm{s}^{-1}$ ). It also corresponded to the highest significant wave height (up to nearly $7 \mathrm{~m}$ ) and longest wave periods ( $9 \mathrm{~s}$ ) Fig. 2B. The sea level rose by about $50 \mathrm{~cm}$ during the onset of the storm (data not shown). Precipitations were restricted to the 12th (53 mm per day) and the 13th of November. The period between 11 and 13 November clearly corresponded to a major winter storm.

Temporal changes in both temperature and salinity measured at a $2 \mathrm{~m}$ depth are presented in Fig. 3. The temperature record outlines the cooling of the water during the whole studied period. Cooling occurred particularly during episodes of dry northerly winds that provoked strong evaporation and mixing. The salinity record showed low values during the beginning of the period under study, especially on 30 October. This corresponded to the intrusion of brackish surface waters as previously reported by Neveux (1975). The storm did not have any pronounced effects on temperature or salinity.

\subsection{Currents, TSM and sedimenting material}

The profile of near bottom current speeds were rather homogeneous with respect to the vertical coordinate. Currents recorded at $23 \mathrm{~m}$ depth were slower than $10 \mathrm{~cm} \mathrm{~s}^{-1}$, 


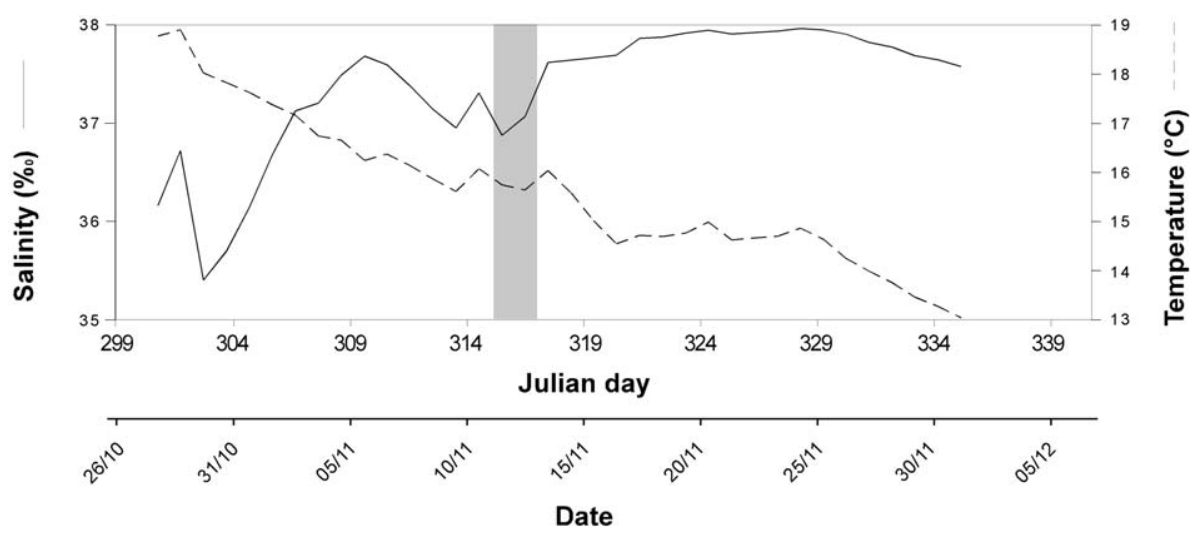

Fig. 3. Temporal changes in temperature and in salinity at $2 \mathrm{~m}$ depth during the period under study. The shaded area corresponds to the storm.

except during the storm where they peak at $35-40 \mathrm{~cm} \mathrm{~s}^{-1}$ Fig. 4A B). Currents were generally northwards, but they flowed southwards during the relaxation period after the storm.

Light transmission was strongly affected by the storm. It dropped from 79 to less than 35\% (CTD measurements), and it took about 18 days for this parameter to reach its pre-storm level. Temporal changes of TSM at $23 \mathrm{~m}$ depth measured from water samples and using both optical and acoustic sensors are shown in Fig. 5A. The storm induced a strong increase of TSM concentration almost up to $50 \mathrm{mg} \mathrm{l}^{-1}$. These maximal values are only available for the ADCP-derived measurements due to the saturation of the OBS and the lack of sampling during the storm. Furthermore, the ADCP-

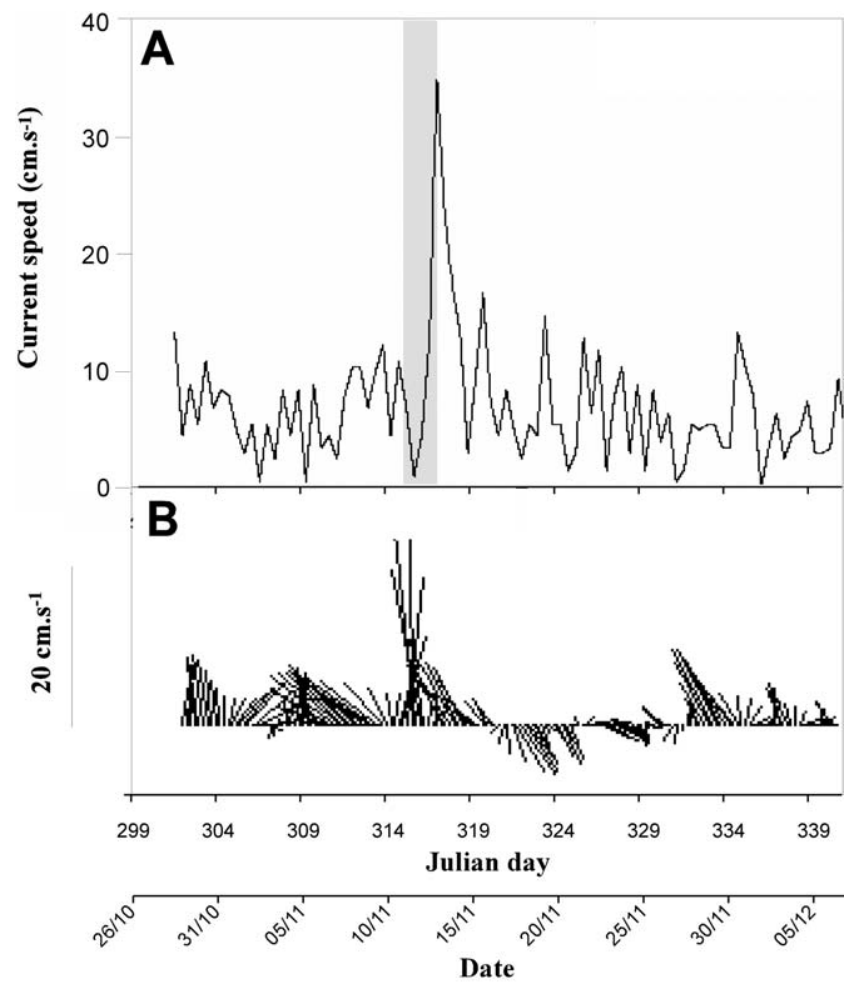

Fig. 4. Temporal changes in the current recorded at $23 \mathrm{~m}$ depth using the RCM9 current-meter. A: current speed, B: stick plot. The shaded area corresponds to the 12 November storm. In B, vertical corresponds to true North. derived TSM recorded $50 \mathrm{~cm}$ above the bottom reached 90 $\mathrm{mg}^{-1}$ during the storm. After the storm, TSM decreased rapidly until 15 November and then more slowly during the next 2 weeks. It was only on 26 November that the impact of the storm completely disappeared as TSM in the whole water column became lower than those measured before the storm.

During most of the studied period, GSR were almost similar at 10 and $23 \mathrm{~m}$ depth Fig. 5B. Differences in peak heights recorded after the storm mainly resulted from different sampling time intervals. At $23 \mathrm{~m}$, the storm induced an increase in GSR by a factor close to 10 . Temporal changes in the carbohydrate and lipid contents of the sediment trap collected material are presented in Fig. 5C.D. On 5 November, concentrations were rather different for the two sets of traps with much higher values in the 23 than in the $10 \mathrm{~m}$ traps. Both carbohydrate and lipid concentrations tended to decline before the storm. This decrease was more pronounced for lipids than for carbohydrates.

\subsection{Nutrients, DOM, plant pigments and bacteria}

Changes in nutrient concentrations with depth tended to be low. The storm induced a significant increase in all nutrient concentrations Fig. 6A,B). This was especially true for $\mathrm{PO}_{4}$. Between 15 and 16 November, there was a significant decrease of $\mathrm{PO}_{4} \cdot \mathrm{PO}_{4}$ concentrations then remained higher $\left(>1 \mathrm{mmol} \mathrm{m}^{-2}\right.$ ) than during the period immediately preceding the storm. The storm induced an increase of integrated $\mathrm{NO}_{3}+\mathrm{NO}_{2}$ and $\mathrm{NH}_{4}$ concentrations by a factor higher than 2. The increase of $\mathrm{NO}_{3}+\mathrm{NO}_{2}$ lasted until 17 November. $\mathrm{NH}_{4}$ showed a general decrease to the end of the survey, while $\mathrm{NO}_{3}+\mathrm{NO}_{2}$ declined to 19 November and then remained almost constant until the end of the survey. The nitrogen/phosphorus ratio always remained high with and was generally between 20 and 40 .

DOC concentrations were between 56 and $90 \mu \mathrm{M}$, DON between 4 and $7 \mu \mathrm{M}$, and DOP between undetectable values and $0.12 \mu \mathrm{M}$. A small decrease in DON and DOC was observed between the beginning and the end of the survey (from 75-100 to 50-75 for DOC and from 6-7 to 4-5 $\mu \mathrm{M}$ for DON). The storm did not induce significant changes in these concentrations. 


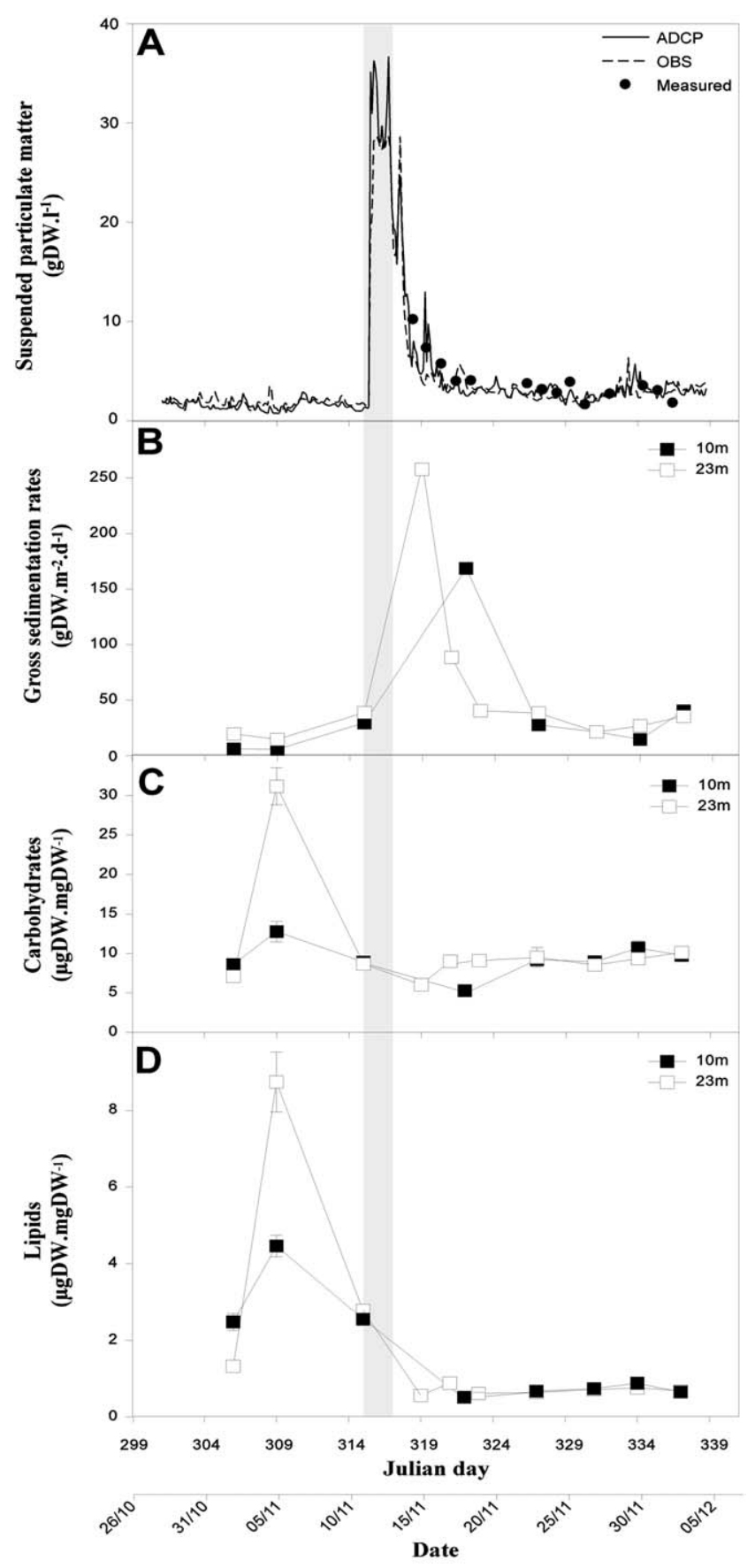

Fig. 5. Temporal changes in concentrations of suspended particulate matter (A), GSRs (B), carbohydrates concentrations of sediment trap collected material (C), and lipid concentrations of sediment trap collected material (D). The shaded area corresponds to the storm.

Chlorophyll $a$ integrated concentrations showed a general decrease during the studied period Fig. 6C). Concentrations, were higher than $80 \mathrm{mg} \mathrm{m}^{-2}$ at the beginning of November and lower than $20 \mathrm{mg} \mathrm{m}^{-2}$ at the beginning of December. Maximal concentrations were associated with the intrusion of low salinity water within the bay. On 2 November, vertical profiles of chlorophyll $a$ showed a clear maximum $\left(4.8 \mu \mathrm{g}^{-1}\right)$ at the surface and a concentration lower than $0.5 \mu \mathrm{g} \mathrm{l}^{-1}$ near the bottom. Concentrations then became

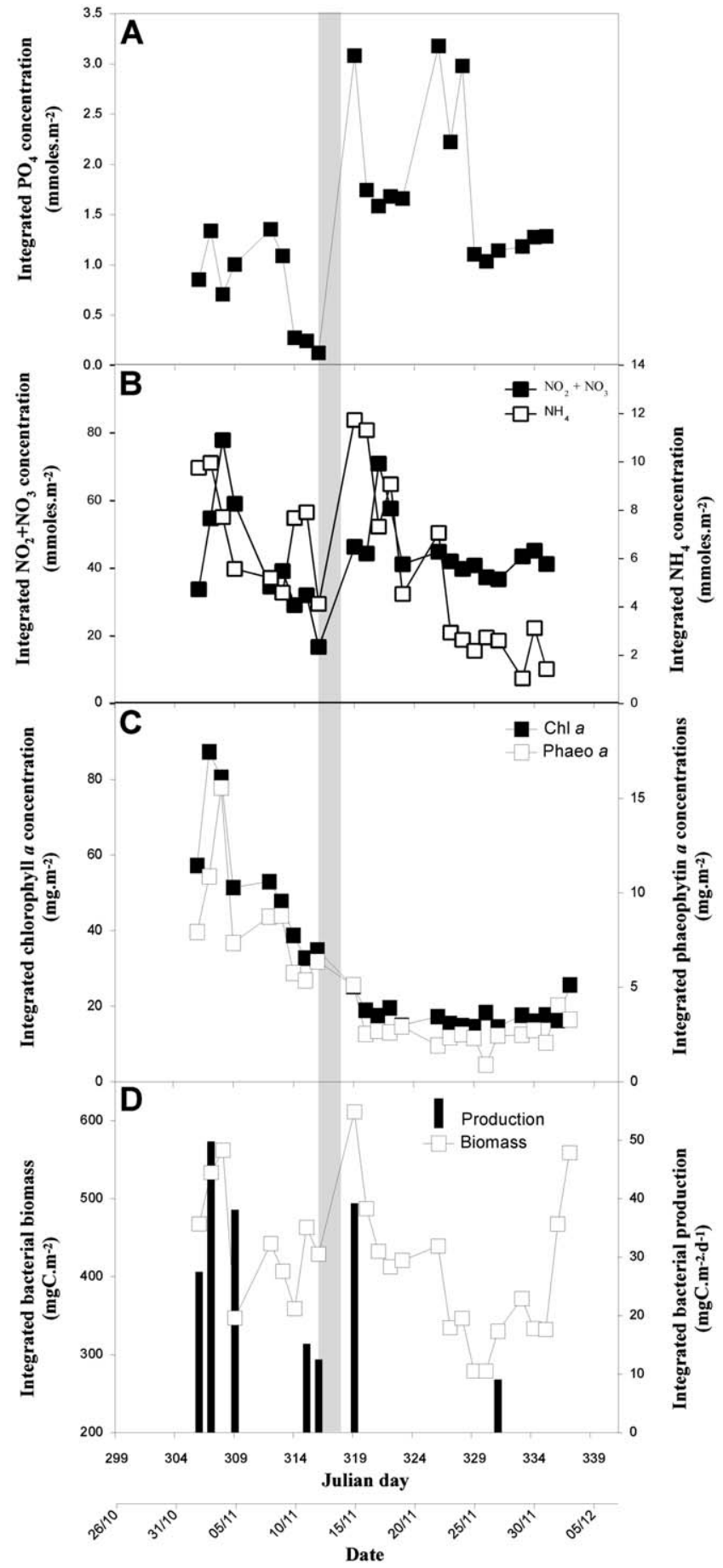

Fig. 6. Temporal changes in concentrations of $\mathrm{PO}_{4}(\mathrm{~A}), \mathrm{NO}_{3}$ and $\mathrm{NO}_{2}+$ $\mathrm{NO}_{3}$ (B), chlorophyll $a$ and phaeophytin $a$ concentration (C), and bacterial biomass and production (D). The shaded area corresponds to the storm.

homogeneous relative to depth and decreased to 0.6 and $0.7 \mu \mathrm{g}^{-1}$ at the beginning of December. Just before the storm, chlorophyll $a$ concentrations were around $1.4 \mu \mathrm{g}^{-1}$ and homogeneous throughout the water column with phaeophytin $a$ /chlorophyll $a$ ratios increasing from 0.14 (surface) to 0.21 (bottom) Fig. 7A . Immediately after the storm, all concentrations decreased to $1 \mu \mathrm{g} \mathrm{l^{-1 }}$ except near the bottom were they remained almost constant $\left(1.5 \mu \mathrm{g}^{-1}\right)$. Phaeophytin 

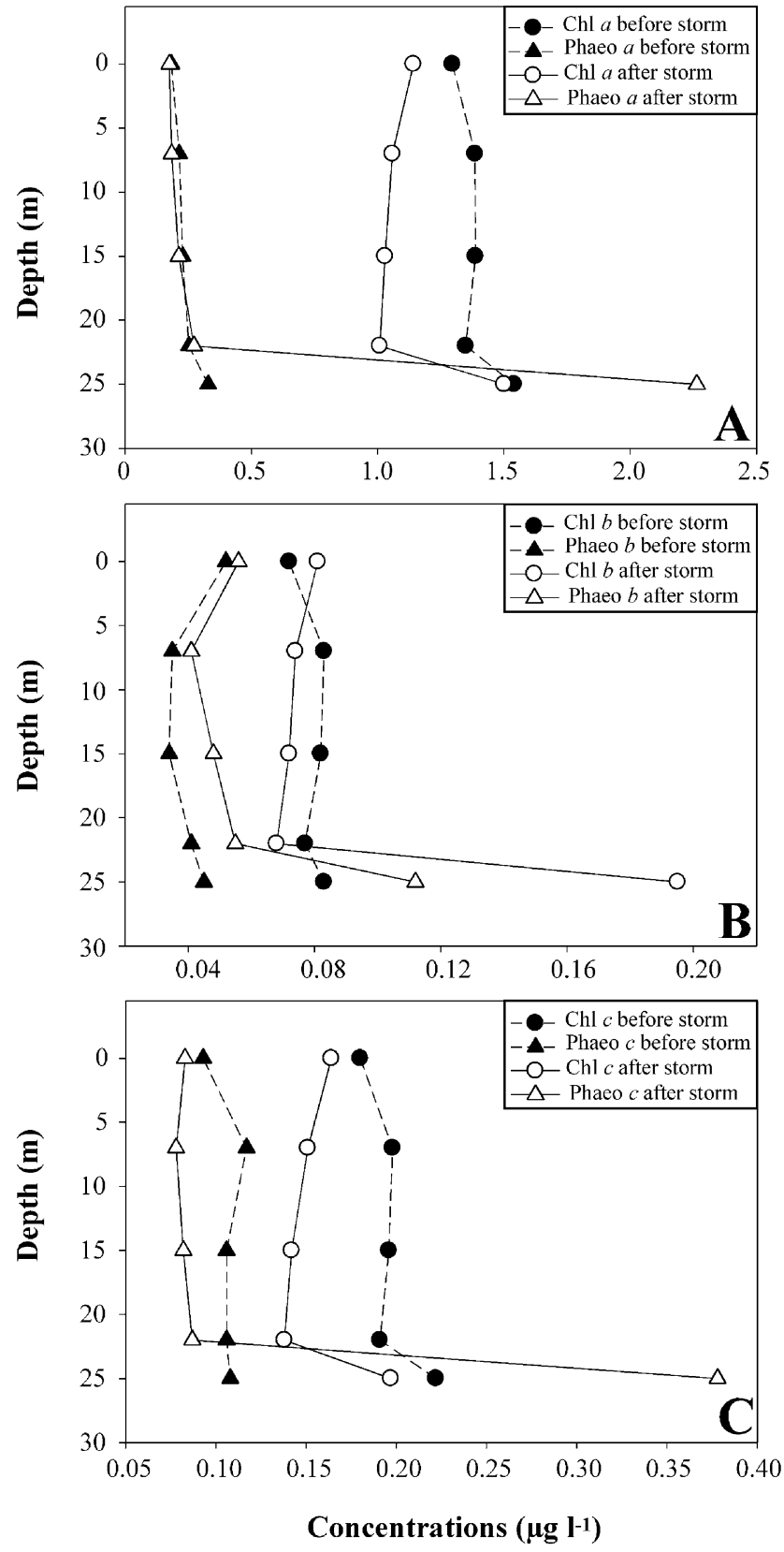

Fig. 7. Comparison of vertical profiles of chlorophyll and phaeophytin $a$ (A), $b(\mathrm{~B})$ and $c(\mathrm{C})$ just before and after the storm.

$a$ concentrations were not affected by the storm except near the bottom where they reached $2.3 \mu \mathrm{g} \mathrm{l}^{-1}$ on 15 November. Consequently phaeophytin $a /$ chlorophyll $a$ ratios weakly increased in the upper part of the water column from 0.15 (surface) to $0.27(22 \mathrm{~m})$, but were higher than 1.5 near the bottom. The effects of the storm on chlorophyll and phaeophytin $b$ concentrations were also mostly restricted to the immediate vicinity of the bottom Fig. 7B. By opposition to what was observed for chlorophyll and phaeophytin $a$, the storm resulted in significant increases in both chlorophyll and phaephytin $b$ near bottom concentrations. Consequently phaeophytin $b$ /chlorophyll $b$ ratios remained close to 0.55 before and after the storm. Changes in chlorophyll and phaeophytin $c$ were almost similar to those recorded for chlorophyll and phaeophytin $a$. They were characterised by a slight decrease of chlorophyll concentrations in the upper part of the water column and by a sharp increase in phaeophytin near bottom concentrations after the storm Fig. 7C. The phaeophytin $c /$ chlorophyll $c$ ratio was thus much lower in the upper part of the water column (0.51) than near the bottom (1.92). The only effects of the storm on plant pigments were thus observed near the bottom with an increase in all phaeophytin concentration, but only an increase in chlorophyll $b$.

Bacterial biomass ranged from 280 to $610 \mathrm{mg} \mathrm{C} \mathrm{m}^{-2}$ and bacterial production from 9 to $50 \mathrm{mg} \mathrm{C} \mathrm{m}^{-2}$ per day Fig. 6D. Temporal changes in both bacterial biomass and production occurred: (1) during the intrusion of low salinity waters, and (2) during the storm. On 2 November, bacterial biomass and production were highly stratified, with maximal values occurring in the surface layer. Then, the salinity decreased and on 3 November, both bacterial biomass and production increased by factors of 1.2 and 1.7. On 5 November, the salinity increased and both bacterial biomass and production decreased by factors of 1.5 and 1.3 . On 12 November (i.e. just before the storm), bacterial production was low throughout the water column. The storm resulted in an increase of both bacterial biomass and production by factors 1.3 and 2.5 (15 November). The vertical distribution of both parameters remained constant throughout the water column, except a high production $(+46 \%)$ and a low biomass $(-25 \%)$ near the seabed (data not shown). The specific activity of bacteria near the seabed was thus twice higher than in overlying waters. Based on right angle scatter signals, we assume that average bacterial size increased by a factor of 1.2 between 12 and 15 November throughout the whole water column. After 2 days (17 November) cell size decreased to pre-storm values. Between 15 and 26 November, bacterial biomass decreased steadily by a factor of 2.2. Bacterial production recorded on 27 November was low (i.e. twice lower than that measured on 15 November). Then, from 27 November to 3 December, bacterial biomass increased abruptly by a factor of 2 .

\subsection{Sediments and meiofauna}

The proportion of particles less than $63 \mu \mathrm{m}$ in size in superficial sediments increased after the storm Fig. 8A to reach $21 \%$ on 18 November. The standard deviations corresponding to most of the sampling dates immediately after the storm were high, suggesting that the deposition of fine particles was heterogeneous at small special scale. Granulometry became equivalent to that before the storm on 25 November. Temporal changes in carbohydrates within superficial sediments were similar to those of the proportion of fines with transitory peak (18 November) associated to high spatial heterogeneity after the storm Fig. 8B. This was not the case for lipids, which did not seem to be affected by the storm (Fig. 8C). Temporal changes in meiofauna abundance showed a decrease by a factor of 2 between 9 and 16 


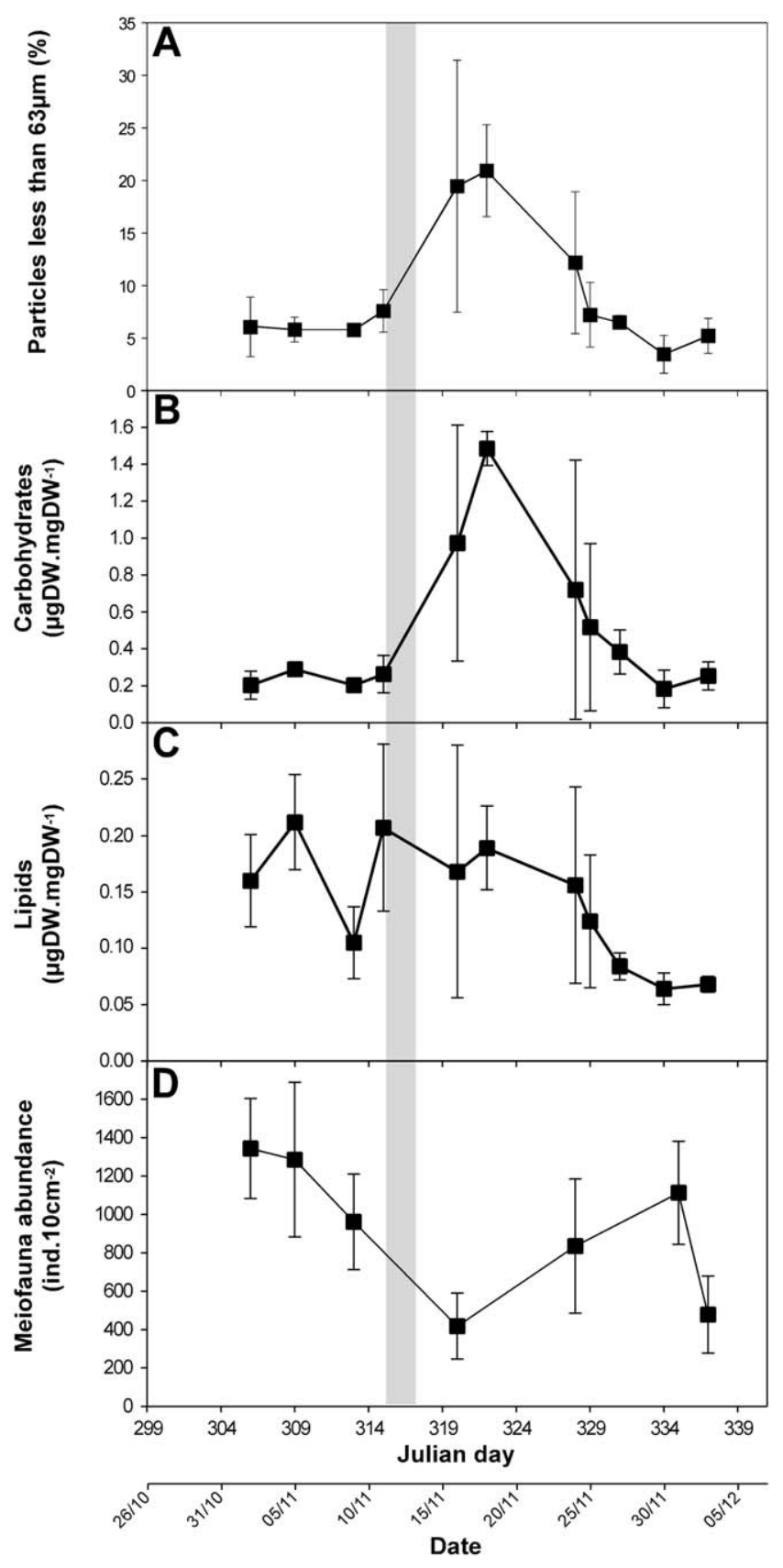

Fig. 8. Temporal changes in superficial sediment characteristics: $\%$ of particles less than $63 \mu \mathrm{m}(\mathrm{A})$, carbohydrate concentration (B), lipid concentration (C), and meiofauna abundance (D). The shaded area corresponds to the storm. Vertical bars are standard deviations.

November Fig. 8D. This decrease started before the storm. Meiofauna population then steadily recovered. The return to initial abundances lasted about 2 weeks.

\section{Discussion}

\subsection{Temporal frequency of severe winter storms}

The temporal variability of the wave characteristics in the south-eastern part of the Gulf of Lion were analysed from the outputs of the Mediterranean wave model Vagmed (MétéoFrance) between April 1996 and December 2000 to assess the relative magnitude of this storm. There were only three major storms, with wave periods $>10 \mathrm{~s}$ and significant heights $>5 \mathrm{~m}$, (17 December 1997, 12 November 1999, and 23 December 2000) during that period of time. Therefore, the storm observed during this study may be considered as an extreme event. During the present study, the bottom stress was estimated according to the wave-current interaction formulation of Soulsby et al. (1993). It peaked at $19 \mathrm{~N} \mathrm{~m}^{-2}\left(43 \mathrm{~N} \mathrm{~m}^{-2}\right)$ using a seabed roughness of $10^{-4} \mathrm{~m}$ (respectively $10^{-3} \mathrm{~m}$ ). These values are much higher than the critical stress required to suspend various types of sediments in the Gulf of Lions (i.e. about $0.1 \mathrm{~N} \mathrm{~m}^{-2}$ according to E. Schaaff, personal communication).

\subsection{Resuspension of nutrients and dissolved organic matter. Responses of the bacterioplanktonic and phytoplanktonic communities}

The storm induced a significant increase of nutrient concentrations in the water column. Nutrients (Blackburn et al., 1996; Denis et al., 2001), and especially ammonium, can be either adsorbed on marine sediment grains (Mackin and Aller, 1984) especially in nearshore areas (Rosenfeld, 1979) or present in interstitial water in concentration much higher than in the overlying water column (Matisoff et al., 1975). During periods of sediment resuspension, desorption of nutrient, from sediment solids can be the major pathway (rather than diffusive flux) for enriching the water column together with bacterial degradation of organic matter in the bottom material (Fanning et al., 1982; Ullman and Sandstrom, 1987; Simon, 1989). During the present study, the increase of nitrate lasted until 17 November as other nutrients declined after the major input due to the storm. This pattern is in agreement with results from previous experimental studies suggesting that resuspension causes a temporary increase in ammonia and subsequent oxidation then produces nitrate (Fanning et al., 1982).

Two non-exclusive hypotheses may explain the increase of both bacterial biomass and production reported in the water column after the storm: (1) the resuspension of benthic bacteria and/or (2) a stimulation of bacterial growth by resuspended material.

The resuspension of benthic bacteria after a storm has been shown to be limited to the first $40 \mathrm{~cm}$ above the watersediment interface (Ritzrau and Graf, 1992) and dominated by particle-attached bacteria (Wainright, 1990). Particleattached bacteria are often considered as more active than free-living bacteria because of an enhanced access to DOC due to hydrolytic release of organic material or to the overcoming of diffusive limitations through turbulent shear (Ritzrau, 1996 and references therein). Therefore, the resuspension of particle-attached bacteria may have contributed to the increase in bacterial production reported on 15 November in the deep layers of the water column. However, most bacteria enumerated by flow cytometry are free-living and 
counting has shown an increase in their biomass after the storm. This suggests that resuspension alone cannot account for the increase in bacterial biomass over the whole water column.

The second hypothesis assumes that growth of bacterioplankton was stimulated by nutrient release from sediments during the storm. During resuspension, desorption of inorganic nutrients from sediments occurs within a few minutes (Simon, 1989) providing an immediate source of nutrients to heterotrophic activity (Wainright, 1987; Ritzrau and Graf, 1992; Sloth et al., 1996). Bacterial communities in Mediterranean coastal areas are often phosphorus limited (Thingstad et al., 1998; Zohary and Robarts, 1998) and ammonium assimilation is generally stimulated by phosphorus supply (Joux et al., unpublished). Therefore, phosphate and ammonium resuspended during the storm may have been quickly assimilated by bacteria, resulting in a marked increase in bacterial biomass and production as well as in mean cell biovolume. Similar increase of the cellular biovolume has been reported after nutrient resuspension and growth stimulation of free-living bacteria (Wainright, 1987). The growth of bacterioplankton was probably not due to the release of labile DOC from sediment because the bulk of the dissolved organic pool in the water column did not change after the storm. Furthermore, the labile fractions of bulk sedimentary organic matter are often low (i.e. $10 \%$ or less; Grant and Hargrave, 1987).

During wintertime microphytobenthos accounts for about a third of integrated phytoplanktonic chlorophyll $a$ (RiauxGobin et al., 1998). Storms may thus affect both benthic microflora and phytoplanktonic populations in the water column.

Near bottom chlorophyll $a$ and $c$ were not affected by the storm, but there was an increase in all phaeophytins and in chlorophyll $b$. As stated above, the current velocity observed during the storm was much higher than critical resuspension thresholds (Jonge and van den Bergs, 1987; Denis and Grenz, 1996). A simple computation shows that the resuspension of all the phaeophytin $a$ present in the first $0.5 \mathrm{~cm}$ of sediment within $2 \mathrm{~m}$ above the bottom would account for the nearbottom concentration measured just after the storm. Along the same line, the analysis of phaeophytin a/chlorophyll $a$ ratios before and after the storm and within superficial sediments (Grémare et al., 1997) suggests that on 15 November, nearly $75 \%$ of the pigments at $25 \mathrm{~m}$ depth originate from the sediments. This clearly demonstrates that resuspension affects near bottom pigment concentrations. There is also evidence suggesting that this effect is not similar for chlorophylls and phaeophytins $a$ and $c$ as indicated by the absence of increase in these chlorophylls near the bottom. This discrepancy probably results from differential resuspension and/or sedimentation between living and detritic materials. The occurrence of differential resuspension has been suggested by Sloth et al. (1996) who reported that less than $2 \%$ of benthic microphytes were transferred to the water column during a simulated storm due to the presence of biofilms
(Delgado et al., 1991). According to these authors, the cohesiveness of microphyte mats increases sediment stability and allows for the washing out of the underlying nonconsolidated sediment without detachment of the mat. In addition, most of benthic diatoms are attached on mud coated sand grains (Jonge, 1985). Aggregation of these particles may enhance their sedimentation and thus contribute to the rapid decrease of chlorophyll $a$ and $c$ in near bottom waters. This may explain why near-bottom chlorophylls $a$ and $c$ concentrations were close to their pre-storm levels on 15 November. Another interesting result from the present study is the increase in near-bottom chlorophyll $b$ during the storm. This suggests that the effects of resuspension and sedimentation differ between pigments. Chlorophyll $b$ is indicative of the presence of Chlorophyceae, Euglenophyceae and Prasinophyceae. Most of these are free and often motile cells, which are probably both easier to resuspend, and able to remain for longer periods of time in the water column than diatoms. This increase in chlorophyll $b$ is thus in agreement with the postulated effects of resuspension and sedimentation on near bottom pigment concentrations. In order to unravel the effects of resuspension and further sedimentation, it would now be interesting to perform intensive sampling immediately after a major winter storm.

We did not observe any significant effect of the storm on integrated phytoplankton biomass. All chlorophyll and phaeophytin concentrations decreased steadily during the whole period under study. Accessory chlorophylls ratio chlorophyll $b /$ chlorophyll $c$ weakly increased in the upper part of the water column after the storm indicating a modification inside the phytoplanktonic community corresponding to an increase of Chlorophyceae compared to Chromophyceae. However, these changes were constant and progressive and probably reflect a normal transition of the populations between fall and winter as previously observed in the Banyulssur-Mer area (Lantoine, 1995). Based on field surveys (Vidussi et al., 2000), mesocosm (Sloth et al., 1996; Ogilvie and Mitchell, 1998) and laboratory experiments (Jonge and van den Bergs, 1987; Nalewajko and Murphy, 1998), it appears that storms may have rather different effects on phytoplanktonic communities. Some studies have reported positive effects linked either to an enhanced nutrient supply (Nalewajko and Murphy, 1998; Ogilvie and Mitchell, 1998; Julius and Goad, 2000), or to the resuspension of living or resting spores (Backhaus et al., 1999). Some negative effects due to water mixing, decreasing temperature and light attenuation have been reported as well (Andersen and Prieur, 2000; Vidussi et al., 2000). At last some surveys did not show any clear effect of storms at all (Sloth et al., 1996). According to most of the authors cited above, storm effects on phytoplankton are short-term (i.e. between 4 and 6 days according to Oviatt et al., 1981 and Sloth et al., 1996) and generally only contribute to accelerate or to slow down the normal evolution of the population (Vidussi et al., 2000). Our own observations thus tend support the relative "resistance" of phytoplankton to such episodic stress. 
In the Bay of Banyuls-sur-Mer phytoplankton is limited by nutrient availability during summer and it has been postulated that autumn blooms result from a superficial eutrophisation induced by easterly storms and/or the flooding of local rivers (Jacques, 1970). Our working hypothesis was thus that winter storm may induce a positive effect on phytoplankton through changes in nutrient concentrations. We did observe an increase in nutrients following the storm (see above) but with no associated change in phytoplanktonic biomass. Such a lack of response may first result from the briefness of the increase in nutrients. Nutrient concentrations indeed declined relatively quickly after the storm probably due to bacterial consumption (see above) and then remained low. The period of increased nutrient availability may thus have been too short to enhance phytoplanktonic production. The storm was clearly a major one and associated resuspension could thus be considered as maximal. However, it was not associated to strong precipitations in the bay of Banyuls-surMer as it is often the case (Jacques, 1970). The lack of phytoplankton response may thus result from the absence of significant continental inputs. In this sense, our results tend to support the hypothesis according to which river flooding is more important than sediment resuspension in controlling autumn phytoplanktonic blooms. Furthermore, there may be some other cues than nutrient availability in controlling phytoplanktonic biomass and some of them may have been negatively affected by such a severe storm. Light transmission sharply dropped during the storm and it took more than 2 weeks for this parameter to reach its pre-storm level. The interaction between this parameter, resuspension and phytoplanktonic biomass has already been pointed out by several authors. In a lagoon, Walker (1981) showed a strong inverse correlation between chlorophyll $a$ concentrations and water transparency due to intermittent resuspension of bottom sediment. Cotner et al. (2000) also attributed the spatial and temporal decoupling in phototrophic and heterotrophic productivity to the decrease in light availability due to resuspension. Regarding the Bay of Banyuls-sur-Mer, Jacques (1970) stated that vertical distribution of phytoplanktonic production is mainly cued by water transparency. Further studies are now needed in order to unravel the respective roles of: (1) river inputs and sediment resuspension in controlling nutrient availability, and (2) nutrient and light availability in controlling phytoplanktonic biomass. The first point may be addressed by monitoring the effects of other storms associated to important precipitations. The second one may benefit from the assessment of the effects of a less severe winterstorm Schubel (1968).

A simultaneous high-frequency monitoring of in vivo fluorescence and pressure carried out during spring 2002 at the study site shows a strong negative effect of an easterly storm on phytoplanktonic biomass and the existence of a 3 weeks long relaxation period (Grémare, unpublished). It should thus be stressed that the response of phytoplankton to such meteorological events may vary with seasons and that the extrapolation of the lack of phytoplanktonic response recorded during the present study is hazardous.

\subsection{Sedimenting POM}

The storm had major effects on the quantitative and the qualitative characteristics of both sedimenting and sedimented POM. It resulted in a sharp increase in TSM concentrations and GSRs through resuspension and sedimentation. It also induced a decrease in carbohydrate and lipid concentrations in the sedimenting material. However, it should be stressed that those decreases were initiated before the storm due to the occurrence of high concentrations on 5 November. These peaks were sharper at $23 \mathrm{~m}$ than at $10 \mathrm{~m}$ depth. They occurred at the end of the intrusion of low salinity and chlorophyll rich waters recorded during the beginning of the survey and may thus be interpreted as resulting from the sedimentation of this phytoplanktonic biomass. In this sense, our results underline the importance of such events on pelagic productivity and benthic/pelagic coupling in the Bay of Banyuls-sur-Mer.

Storms may affect the concentration of sedimenting POM by different pathways: (1) continental inputs due to increase in river runoffs, (2) exportation to the land due to water spray, (3) resuspension of inorganic particles, and (4) changes in the proportions of several sources of POM presenting different biochemical characteristics. It is difficult to unravel the relative importance of these mechanisms based on the results of the present survey. However, it is clear that in the Banyulssur-Mer area, rainfalls were relatively low during the storm, suggesting that inputs from river (i.e. the Baillaury River) runoffs remained rather limited (see also the discussion regarding phytoplankton). We unfortunately have no data on the export through spray formation, which has already been suspected to account for a loss of POM during storms (Cooper and Jackson, 1999). However, based on TSM concentrations (which were multiplied by 10 during the storm) and on carbohydrate concentrations (which were divided by 2 during the storm), it seems that the storm indeed resulted in an increase in the amount of suspended POM despite of eventual spray formation. Differences in sedimenting POM concentrations were much more pronounced for lipids than for carbohydrates. Grémare et al., 2003 compared the lability of several classes of biochemical compounds based on the characteristics of the regression models linking their concentrations and GSRs. They concluded that carbohydrates are associated to a much more refractory fraction than lipids. Therefore, our results suggest that resuspension is not only affecting inorganic material but also sedimentary organics, which is likely to be more degraded. There are some other evidences for the occurrence of such refractory suspended POM after the storm. Based on weekly sampling, LopezLegentil (2001) recently monitored changes in the enzymatically hydrolysable to total hydrolysable amino acids at the same site between March 1997 and April 1998. This ratio accounts for the proportion of the amino acid pool that can indeed be used by benthic primary consumers (Mayer et al., 
1995; Medernach et al., 2001). Lopez-Legentil (2001) recorded the lowest value of this ratio just after the 17 December 1997 storm (see above). Major winter storms thus not only increase particle loads but also result in a mixing with (more) refractory POM originating from resuspension.

These two mechanisms both interfere with the nutrition of benthic suspension-feeders. Based on a field survey, Cranford et al. (1998) concluded that storms do not induce significant changes in the clearance rate of the clam Placopecten magellanicus. However, these authors also reported a significant positive correlation between POM concentration and absorption rates. They also underlined that food acclimation may be of importance in regulating bivalve nutrition. Cranford (1995) estimated the duration of such a period to 6 days in P. magellanicus. During the present study, the duration of the time period required for a return to initial suspended matter concentrations near the water-sediment interface was close to 2 weeks. Therefore, one cannot rule out that food acclimation mechanisms may take place after major winter storms within the Bay of Banyuls-sur-Mer. Moreover, Grémare et al. (1997) defined two different time periods based on temporal changes in GSRs and in the organic concentrations of sediment trap collected material. The spring-summer period is characterised by low GSRs and high organic contents, whereas the autumn-winter period is characterised by highly variable GSRs and generally low organic contents. Both of these periods last for several months (Grémare et al., 1997; Medernach et al., 2001). They may thus induce different digestive acclimation in suspension-feeding organisms as well.

\subsection{Sedimented POM and benthic meiofauna}

Another consequence of the storm is the transitory accumulation of fine particles at the surface of the sediment. A similar pattern was recorded at the same station by LopezLegentil (2001) following the 17 December 1997 storm. During the period studied by this author, there have been two other least severe storms. None of them was associated to a significant change in superficial sediment granulometry. It thus appears that this process is associated with major winter storms only. The disappearance of fine particles following the storm is probably linked to the characteristics of the hydrodynamism at this sandy station. In this sense, similar studies carried out at deeper muddy stations may prove interesting.

Particle size affects sedimentary organic concentrations through surface availability (Mayer, 1994). It is thus not surprising that the increase in the proportion of fine particles following the storm was concomitant with a sharp increase in carbohydrate concentrations. As already observed for the sediment trap collected materials, lipids behave in a very different way with no clear impact of the storm. This is indicative of the refractory nature of the POM associated to these particles (see above). This result is further supported by the very low value of the enzymatically hydrolysable to total hydrolysable amino acids ratio following the 17 December
1997 storm (Lopez-Legentil, 2001). This particular value was indeed the lowest of the whole period under study, which underlines the effects of major storms relative to those of other sources of variations occurring during a whole year cycle.

During the storm, meiofauna abundance decreased by a factor 2. This result is in good agreement with existing data suggesting that shelf meiofauna populations can be significantly affected by storms (Thistle et al., 1995). Interestingly, and even if caution should be taken due to important spatial heterogeneity, this decrease seems to start before the storm. This could suggest that benthic meiofauna may anticipate the storm for example by burying deeper in the sediment. Thistle et al. (1995) ruled out this hypothesis by comparing meiofauna distributions during a moderate storm and a laboratory flume experiment. To our knowledge, there are no such observations for nematodes, which are largely dominant at our site. Nematode contributions to total meiofauna abundance remained higher than $90 \%$ during the whole period under study. Immediately before the storm, this contribution was of $93.7 \%$ on 5 November versus $91.0 \%$ on 8 November. This difference is largely insignificant, and it is therefore, unlikely that the decrease in total meiofauna abundance between these two dates results from a burial of nematodes in deep sediments. According to Thistle et al. (1995), energy reserves of adult male copepods decrease after 2 days of resuspension whereas those of active females are maintained due to feeding in the water column (Suderman and Thistle, 1998). Here again, there are no such data available for nematodes. Nevertheless, it should be underlined that the time duration requested for complete recovery after the storm was almost equivalent for TSM and meiofauna abundance. It is, therefore, difficult to determine whether the increase of meiofauna after the storm is due to lateral colonisation or to sedimentation.

It is also interesting to consider that the beginning of meiofauna bust occurred simultaneously with the maximal concentrations of sediment trap materials both in carbohydrates and lipids. In a recent study (Grémare et al., unpublished), we assessed the effects of different levels of organic inputs at the water-sediment interface on the deposit-feeding bivalve Abra ovata. There was a clear negative effect at the highest of the four tested concentrations, which may constitute an alternative hypothesis for the uncoupling between the decrease in meiofauna abundance and the storm.

\section{Acknowledgements}

This work was funded through the "Action de Recherche Thématique" no. 1 of the French "Programme National Environnement Côtier". Thanks are due to the crew of the RV Nereis and the professional divers of the Observatoire océanologique de Banyuls-sur-Mer for their assistance in sometimes rough weather conditions. We also deeply thank all the technicians who were involved in various aspects of 
this work. This manuscript greatly benefited from the comments of two anonymous reviewers.

\section{References}

Andersen, V., Prieur, L., 2000. One-month study in the open NW Mediterranean Sea (DYNAPROC experiment May 1995): overview of the hydrobiogeochemical structures and effects of wind events. Deep-Sea Res. 47, 397-422.

Arfi, R., Bouvy, M., 1995. Size, composition and distribution of particles related to wind induced resuspension in a shallow tropical lagoon. J. Plank. Res. 17, 557-574.

Arfi, R., Bouvy, M., Guiral, D., 1994. Sedimentation modified by wind induced resuspension in a shallow tropical lagoon (Côte d'Ivoire. Neth. J. Aquat. Ecol. 28, 427-431.

Arfi, R., Guiral, D., Bouvy, M., 1993. Wind induced resuspension in a tropical lagoon. Estuar. Coast. Shelf Sci. 36, 587-604.

Backhaus, J.O., Wehde, H., Hegseth, E.N., Kaempf, J., 1999. Phytoconvection: the role of oceanic convection in primary production. Mar. Ecol. Progr. Ser. 189, 77-92.

Barnes, H., Blackstock, J., 1973. Estimation of lipids in marine animals and tissues: detailed investigation of the sulphophosphovanillin method for 'total' lipids. J. Exp. Mar. Biol. Ecol. 12, 103-118.

Blackburn, T.H., Hall, P.O.J., Hulth, S., Landen, A., 1996. Organic-N loss by efflux and burial associated with a low efflux of inorganic $\mathrm{N}$ and with nitrate assimilation in arctic sediments (Svalbard, Norway). Mar. Ecol. Progr. Ser. 141, 283-293.

Bouvy, M., Arfi, R., Guiral, D., 1994. Short-term variation of seston characteristics in a shallow tropical lagoon: effect of wind-induced resuspension. Neth. J. Aquat. Ecol. 28, 433-440.

Cauwet, G., 1994. HTCO method for dissolved organic carbon analysis in seawater: influence of catalyst on blank estimation. Mar. Chem. 47, $55-64$.

Charles, F., Amouroux, J.M., Grémare, A., Baudart, J., 1995. A bioassay approach to temporal variation in the nutritional value of sediment trap material. J. Exp. Mar. Biol. Ecol. 191, 65-81.

Cotner, J.B., Johengen, T.H., Biddanda, B.A., 2000. Intense winter heterotrophic production stimulated by benthic resuspension. Limnol. Oceanogr. 45, 1672-1676.

Cranford, P.J., 1995. Relationships between food quantity and quality and absorption efficiency in the sea scallop Placopecten magellanicus (Gmelin). J. Exp. Mar. Biol. Ecol. 189, 124-142.

Cranford, P.J., Emerson, C.W., Hargrave, B.T., Milligan, T.G., 1998. In situ feeding and absorption responses of sea scallops Placopecten magellanicus (Gmelin) to storm-induced changes in the quantity and composition of seston. J. Exp. Mar. Biol. Ecol. 219, 45-70.

Delgado, M., de Jonge, V.N., Peletier, H., 1991. Experiments on resuspension of natural microphytobenthos populations. Mar. Biol. 108, 321328.

Demers, S., Therriault, J.C., Bourget, E., Bah, A., 1987. Resuspension in the shallow sublittoral zone of a marotidal estuarine environment: wind influence. Limnol. Oceanogr. 32, 327-339.

Denis, L., Grenz, C., 1996. Experimental study of microphytobenthos resuspension. C. R. Acad. Sci. Paris 319, 529-535.

Denis, L., Grenz, C., Alliot, E., Rodier, M., 2001. Temporal variability in dissolved inorganic nitrogen fluxes at the sediment-water interface and related annual budget on a continental shelf (NW Mediterranean. Oceanol. Acta 24, 85-97.

Dubois, M., Gilles, K.A., Hamilton, J.K., Rebers, P.A., Smith, F., 1956. Colorimetric method for determination of sugars and related substances. Anal. Chem. 28, 350-356.

Fanning, K.A., Carder, K.L., Betzer, P.R., 1982. Sediment resuspension by coastal waters: a potential mechanism for nutrient re-cycling on the ocean's margins. Deep-Sea Res. 29, 953-965.
Furhman, J.A., Azam, F., 1982. Thymidine incorporation as a measure of heterotrophic bacterioplankton production in marine surface waters: evaluation and field results. Mar. Biol. 66, 109-120.

Gabrielson, J.O., Luketelich, R.J., 1985. Wind related resuspension of sediment in the Peel-Harvey estuarine system. Estuar. Coast. Shelf Sci. 2, $135-145$.

Grant, J., Hargrave, B.T., 1987. Benthic metabolism and the quality of sediment organic carbon. Biol. Oceanogr. 4, 243-264.

Grémare, A., Amouroux, J.M., Charles, F., Dinet, A., Riaux Gobin, C., Baudart, J., Medernach, L., Bodiou, J.Y., Vétion, G., Colomines, J.C., Albert, P., 1997. Temporal changes in the biochemical composition and nutritional value of the particulate organic matter available to surface deposit-feeders: a 2-year study. Mar. Ecol. Prog. Ser. 150, 195-206.

Grémare, A., Amouroux, J.M., Charles, F., Medernach, L., Jordana, E., Nozais, C., Vétion, G., Colomines, J.C., 1998. Temporal changes in the biochemical composition of particulate organic matter sedimentation in the Bay of Banyuls-sur-mer. Oceanol. Acta 21, 783-792.

Grémare, A., Medernach, L., DeBovée, F., Amouroux, J.M., Dinet, A., Albert, P., Colomines, J.C., 2003. Relationships between sedimentary organic matter and benthic fauna within the Gulf of Lions: synthesis on the identification of new biochemical descriptors of sedimentary organic nutritional value. Oceanol. Acta.

Jacques, G., 1970. Aspects quantitatifs du phytoplancton de la région de Banyuls sur Mer (golfe du Lion). IV. Biomasse et production, 19651969. Vie Milieu 20, 279-316.

Jonge, V.N., 1985. The occurrence of epipsammic diatom populations: A result of integration between physical sorting of sediment and certain properties of diatom species. Estuar. Coast. Shelf Sci. 21, 607-622.

Jonge, V.N., van den Bergs, J., 1987. Experiments on the resuspension of estuarine sediments containing benthic diatoms. Estuar. Coast. Shelf Sci. $24,725-740$.

Julius, M.L., Goad, L., 2000. Relationship between periodic resuspension events and phytoplankton blooms in Lake Michigan. J. Phycol. 36 (, 24).

Koroleff, F., 1969. Direct determination of ammonia in natural waters as indophenol blue. Int. Counc. Explor. Sea C M, C:9.

Lantoine, F., 1995. Caractérisation et distribution des différentes populations du picoplancton (picoeucaryotes, Synechococcus spp., Prochlorococcus spp.) dans diverses situations trophiques (Atlantique tropical, golfe du Lion). Thèse de Doctorat de l'Université Pierre et Marie Curie, Paris $265 \mathrm{p}$.

Lebaron, P., Parthuisot, N., Catala, P., 1998. Comparison of blue nucleic acid dyes for enumeration of total bacteria in aquatic ecosystems. Appl. Environ. Microbiol. 64, 1725-1730.

Lee, S., Furhman, J.A., 1987. Relationships between biovolume and biomass of naturally derived marine bacterioplankton. Appl. Environ. Microbiol. 53, 1298-1303.

Lopez-Legentil, S., 2001. Variations temporelles des caractéristiques biochimiques de la matière organique particulaire présente en zone côtière. Comparaison des signaux enregistrés dans des pièges à particules et à la surface du sédiment. Rapp. DEA Université Pierre et Marie Curie 29 p.

Mackin, J.E., Aller, R.C., 1984. Ammonium adsorption in marine sediments. Limnol. Oceanogr. 29, 250-257.

Matisoff, G., Bricker, O.P., Holdren, G.R., Kaerk, P., 1975. Spatial and temporal variations in the interstitial waters chemistry of Cheasapeake Bay sediments. In: Church, T.M. (Ed.), Marine Chemistry in the Coastal Environment, American Chemical Society Symposium Series 18. Washington, DC. pp. 343-363.

Mayer, L.M., 1994. Surface area control of organic carbon accumulation in continental shelf sediments. Geochim. Cosmochim. Acta 58, 12711284.

Mayer, L.M., Schick, L.L., Sawyer, T., Plante, C.J., Jumars, P.A., Self, R.L., 1995. Bioavailable amino acids in sediments: a biomimetic, kineticbased approach. Limnol. Oceanogr. 40, 511-520.

Medernach, L., Grémare, A., Amouroux, J.M., Colomines, J.C., Vétion, G., 2001. Temporal changes in the amino acid contents of particulate organic matter sedimenting in the Bay of Banyuls-sur-Mer (northwester Mediterranean. Mar. Ecol. Prog. Ser. 214, 55-65. 
Nalewajko, C., Murphy, T.P., 1998. A bioassay to assess the potential effects of the sediment resuspension on phytoplankton community composition. J. Appl. Phycol. 10, 341-348.

Neveux, J., Lantoine, F., 1993. Spectrofluorometric assay of chlorophylls and phaeopigments using the least squares approximation technique. Deep-Sea Res. 40, 1747-1765.

Ogilvie, B.G., Mitchell, S.F., 1998. Does sediment resuspension have persistent effects on phytoplankton? Experimental studies in three shallow lakes. Freshwater Biol. 40, 51-53.

Oviatt, C.A., Carlton, D.H., Vargo, G.A., Kopchynski, K.W., 1981. Simulation of a storm event in marine microcosms. J. Mar. Res. 39, 605-626.

Pearson, T.H., Rosenberg, R., 1978. Macrobenthic succession in relation to organic enrichment and pollution of the marine environment. Oceanogr. Mar. Biol. Ann. Rev. 16, 229-311.

Pujo-Pay, M., Raimbault, P., 1994. Improvement of the wet-oxidation procedure for simultaneous determination of particulate organic nitrogen and phosphorus collected on filters. Mar. Ecol. Progr. Ser. 105, 203-207.

Riaux-Gobin, C., Vétion, G., Neveux, J., Duchêne, J.C., 1998. Microphytobenthos et phytoplancton en baie de Banyuls (Golfe du Lion): biomasses pigmentaires et facteurs hydroclimatiques. Vie Milieu 48, 1-13.

Ritzrau, W., 1996. Microbial activity in the benthic boundary layer: smallscale distribution and its relationship to the hydrodynamic regime. J. Sea Res. 36, 171-180.

Ritzrau, W., Graf, G., 1992. Increase of microbial biomass in the benthic turbidity zone of the Kiel Bight, Baltic Sea, after resuspension by a storm event. Limnol. Oceanogr. 37, 1081-1086.

Rosenfeld, J.K., 1979. Ammonium adsorption in nearshore anoxic sediments. Limnol. Oceanogr. 24, 356-364.

Schubel, J.R., 1968. Suspended sediment of northern Chesapeake Bay. Chesapeake Bay Institute Technical Report 35. pp. 264.

Servais, P., Lavandier, P., 1995. Mesures de production bactérienne par incorporation de thymidine et de leucine marquées: discussion des protocoles expérimentaux et exemples d'application. Océanis 21, 161-189.

Shideler, G.L., 1984. Suspended sediment responses in a wind documented estuary of the Texas Gulf coast. J. Sedim. Petrol. 54, 731-745.

Simon, N.S., 1989. Nitrogen cycling between sediment and the shallow water column in the transition zone of the Potomac river and estuary. II. The role of wind driven resuspension and absorbed ammonium. Estuar. Coast. Shelf Sci. 28, 531-547.
Sloth, N.P., Riemann, B., Nielsen, L.P., Blackburn, T.H., 1996. Resilience of pelagic and benthic microbial communities to sediment resuspension in a coastal ecosystem, Knebel Vig, Denmark. Estuar. Coast. Shelf Sci. 42, $405-415$.

Soulsby, R.L., Hamm, L., Klopman, G., Myrhaug, D., Simons, R.R., Thomas, G.P., 1993. Wave-current interaction within and outside the bottom boundary layer. Coastal Eng. 21, 41-69.

Thingstad, T.F., Zweifel, U.L., Rassoulzadegan, F., 1998. P limitation of heterotrophic bacteria and phytoplankton in Northwest Mediterranean. Limnol. Oceanogr. 43, 88-94.

Thistle, D., Weatherly, G.L., Ertman, S.C., 1995. Shelf harpacticoid copepods do not escape into the seabed during winter storms. J. Mar. Res. 53, 847-863.

Tréguer, P., Le Corre, P., 1975. Manuel d'analyses des sels nutritifs dans l'eau de mer. Laboratoire d'Océanographie Chimique, Université de Bretagne Occidentale, Brest 110 p.

Troussellier, M., Courties, C., Zettelmaier, S., 1995. Flow cytometric analysis of coastal lagoon bacterioplankton and picoplankton: fixation and storage effects. Estuar. Coast. Shelf Sci. 40, 621-633.

Ullman, W., Sandstrom, M.W., 1987. Dissolved nutrient fluxes from near shore sediments of Bowling Green Bay, Central Great Barrier Reef Lagon Australia. Estuar. Coast. Shelf Sci. 24, 289-303.

Vidussi, F., Marty, J.C., Chiavérini, J., 2000. Phytoplankton pigment variations during the transition from spring bloom to oligotrophy in the northwestern Mediterranean sea. Deep-Sea Res. 47, 423-445.

Wainright, S.C., 1987. Stimulation of heterotrophic microplankton production by resuspended marine sediments. Science 238, 1710-1712.

Wainright, S., 1990. Sediment-to-water fluxes of particulate material and microbes by resuspension and their contribution to the planktonic food web. Mar. Ecol. Progr. Ser. 62, 181-271.

Walker, T.A., 1981. Dependence of phytoplankton chlorophyll on bottom resuspension in Cleveland Bay, Northern Queensland. Aust. J. Mar. Freshwater Res. 32, 981-986.

Weir, D.J., MacManus, J., 1987. The role of wind in generating turbidity maxima in the Tay Estuary. Cont. Shelf Res. 7, 1315-1318.

Zohary, T., Robarts, R.D., 1998. Experimental study of microbial P limitation in the Eastern Mediterranean. Limnol. Oceanogr. 43, 387-395. 